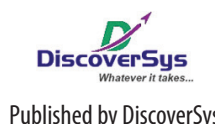

Published by DiscoverSys

\section{Factors associated to first line antiretroviral therapy (ART) failure among HIV/AIDS patients at Sanglah Hospital, Bali}

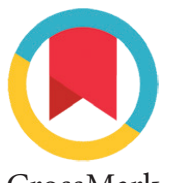

CrossMark
Cok Istri Sri Dharma Astiti, ${ }^{1,2^{*}}$ Anak Agung Sagung Sawitri, ${ }^{2,3}$ Ketut Tuti Parwati Merati ${ }^{2,4}$
Background and purpose: The incidence of first line ART failure is increasing in the South East Asia region. The main referral hospital in Bali has recorded an increased use of second line ART due to the first line ART failure. This study aims to explore risk factors associated to first line ART failure.

Methods: A case control study was conducted among people living with HIV and AIDS at Sanglah Hospital Denpasar who started first line ART between 2004 and 2013. Cases were those who diagnosed as having clinical treatment failure and still on treatment in 2015. Controls were those with no treatment failure. Sex and year of ART initiation were matched between case and control. Data were obtained from medical records that include initial regiments, HIV mode of transmission, the WHO HIV clinical stage, CD4 count, opportunistic infections, body mass index, hemoglobin level, and drug substitution at the beginning and during treatment. Risk factors were analysed using logistic regression.

Results: Out of 68 HIV/AIDS patients with clinical ART failure, 72.1\% were confirmed with immunological and $36.8 \%$ were confirmed with virological failure. Median time before treatment failure was 3.5 years. Factors associated to ART failure were HIV clinical stage IV ( $A 0 R=3.43 ; 95 \% C l: 1.65-7.13$ ) and being widow/widower $(A 0 R=4.85$; 95\%Cl: 1.52-15.53). Patients with TB co-infection have a lower risk for treatment failure due to early diagnosis and treatment through TB-HIV program ( $A O R=0.32 ; 95 \% \mathrm{Cl}: 0.14-0.70)$.

Conclusions: Higher HIV clinical stage at ART initiation increases the risk of treatment failure. HIV-TB co-infection indirectly reduces the risk of treatment failure.
${ }^{1}$ Bali Provincial Health Office, 2Public Health Postgraduate Program Udayana University, ${ }^{3}$ Department of Community and Preventive Medicine Faculty of Medicine Udayana University, ${ }^{4}$ Department of Internal Medicine Faculty of Medicine Udayana University/Sanglah General Hospital
*Correspondence to:

Cok Istri Sri Dharma Astiti, Bali Provincial Health Office, Public Health Postgraduate Program Udayana University cokistrisri_dharmaastiti@yahoo. co.id

Keywords: treatment failure, first-line ART, HIV/AIDS, Bali

Cite This Article: Astiti, C.I.S.D., Sawitri, A.A.S., Merati, K.T.P. 2017. Factors associated to first line antiretroviral therapy (ART) failure among HIV/AIDS patients at Sanglah Hospital, Bali. Public Health and Preventive Medicine Archive 5(1): 3-8. D0l:10.15562/phpma.v5i1.33

\section{INTRODUCTION}

People living with HIV and AIDS (PLWHA) require a long-life antiretroviral treatment (ART) to reduce viral load and to prevent infections, drug resistance, complications and AIDS-related deaths. ${ }^{1}$ Long term ART is associated with lack of treatment adherence which leads to treatment failure and drug resistance. ${ }^{2}$ The scaled-up of first line ART globally may contribute to the increase of ART failure. ${ }^{3}$ First line ART failure increases the need for second line ART that are more expensive with higher adverse effects and demand more advance healthcare facilities. ${ }^{4-7}$ Globally, as many as 14.9 million PLWHA were on ART in 2014 for which $94.8 \%$ were on first line ART. ${ }^{8}$ The average incidence of ART failure in Sub-Saharan African countries is 2.65 per 100 person years, while in the South East Asian countries is only less than 5\%., ${ }^{9,10}$ In Indonesia, from 160,138 PLWHA as many as $97.03 \%$ were on first line ART in $2014^{11}$ however until now the rate of treatment failure is still unknown.

Studies have revealed that ART failure is associated with factors prior to ART initiation and during the treatment, however these studies are still inconsistent. Factors prior to ART initiation that contribute to ART failure are HIV clinical stage IV and lower CD4 count. ${ }^{12-18}$ During the treatment, lack of adherence and period of treatment contribute to treatment failure. ${ }^{17-24}$ Several other studies have evaluated association between treatment failure and clinical indicators such as opportunistic infections (OIs), drug regiments, modes of HIV transmission, haemoglobin level, body mass index (BMI), drug toxicity and first line ARV resistence. ${ }^{15,16,20,25,26}$ These studies have also examined relationship between treatment failure and sociodemographic variables such as age, sex, employment, education level and marital status. ${ }^{12,15,17,21,26-28}$

Data from Bali Provincial Health Office in 2015 showed that as many as $96.2 \%$ of 1,173 HIV/AIDS patients were on first line ART. ${ }^{29}$ In 2015, there were 54 voluntary counselling and testing (VCT) facilities available across Bali Province, seven hospitals/clinics providing first line ART and only three hospitals providing second line ART. One among those health facilities that is able to provide comprehensive care including ART for HIV/ AIDS patients is Sanglah General Hospital. Until 2015, a total of 2,431 HIV/AIDS patients had ever 
accessed ART from this hospital. In addition, a total of 152 clients were on second line ART or $84 \%$ of the total second line ART in Bali Province. Until recently, limited studies have been undertaken in Indonesia to explore factors associated with ART failure. An understanding on factors associated to ART failure is essential for designing effective intervention strategies to prevent treatment failure.

\section{METHODS}

A case control study was conducted at Sanglah Hospital. Primary data source in this study was medical record. Other data sources included pre-ART register, ART register and drug delivery register. Researcher also conducted crosschecking information from nurses and doctors.

Cases were PLWHA and fulfil the following criteria: 1) adult patient who had diagnosed to be ART failure by medical doctor; 2) starting or continuing ART at Sanglah Hospital between August 2004 and December 2013; 3) still on ART between January and December 2015 and 4) having a complete medical record on pre-ART, during ART and follow-up visit until the ART failure occurred. Controls were PLWHA without treatment failure that fulfilled criteria number 2, 3 and 4. Case and control ratio was 1:2. Cases and controls were selected using different sampling methods. Cases were selected from 118 PLWHA who were on second line ART until December 2015. Only 68 patients met the case criteria and the rest were excluded due to several reasons that include child (6 cases), allergic (14 cases), unavailability of prior to ART data (20 cases), and incomplete medical record (10 cases). Controls were conveniently selected from 1,831 medical records. Medical records were reviewed against the control selection criteria. Cases and controls were matched for sex and year of initiating ART. This strategy was implemented until 136 controls were selected.

This study defined ART failure based on the standard operational procedure of Sanglah Hospital. Clinical ART failure is confirmed if first line ART has been taken for at least 6 months with observed clinical improvements followed by clinical deterioration such as the presence of OIs. Immunological examination (CD4 count) was not regularly performed even though it is a routine procedure. Viral load could not either be routinely conducted due to limited access. Immunologically, ART failure is defined if CD4 count remains the same or reduces up to $50 \%$ from initial CD4 count, while virologically if viral load count remains the same or increases more than 5,000 copies $/ \mathrm{ml}$ from initial viral load count. Risk factors that examined in this study were sociodemographic and clinical variables. Clinical variables included all variables at ART initiation and during ART. Sociodemographic variables included age, level of education, employment and marital status at ART initiation and during ART. Clinical variables at ART initiation were modes of HIV transmission, first line ART regiments, the most frequent OIs, the WHO HIV clinical stage (stage I-IV), CD4 count, haemoglobin level, and BMI. Clinical variable during first line ART was history of drug substitution due to adverse reactions or side effects. Modes of HIV transmission were defined as potential sources for acquiring HIV that included those with high risk sexual behavior, partner of PLWHA, and injecting drug user. OIs in this study included candidiasis (oral and oro-esophageal), tuberculosis, and hepatitis.

Univariate and bivariate analysis were conducted for each identified risk for ART failure to obtain crude odd ratio. Variables with $p<0.25$ on bivariate analysis were included in the multivariate analysis. Prior to multivariate analysis, correlation test between variables was performed. If a strong correlation $(r>0.6 ; p<0.05)$ was found, only one variable will be included in the multivariate analysis. Logistic regression using combination of enter and backward methods was performed to calculate adjusted odd ratio (AOR), p-value and 95\%CI.

The study protocol has been approved by Human Research Ethics Committee of Faculty of Medicine Udayana University/Sanglah General Hospital.

\section{RESULTS}

Sixty-eight HIV/AIDS patients were confirmed as clinical ART failure with median time of 3.5 years. Forty-nine $(72.1 \%)$ were confirmed as immunological failure with median time of 3.7 years $(95 \% \mathrm{CI}$ : 2.7-5.1) and 25 (36.8\%) were confirmed as virological failure with median time of 4.1 years $(95 \% \mathrm{CI}$ : 3.2-5.1).

Characteristics between cases and controls were comparable for sex $(\mathrm{p}=1.000)$, year of initiating ART $(\mathrm{p}=0.803)$, religion $(\mathrm{p}=0.659)$, place of HIV testing $(\mathrm{p}=0.178)$, domicile $(\mathrm{p}=0.411)$ and the government insurance ownership $(\mathrm{p}=0.162)$.

Table 1 shows the crude OR of sociodemographic variables that include education level, employment status, age, and marital status with treatment failure. Table 2 shows the crude OR of clinical variables and treatment failure. Bivariate analysis revealed that the HIV clinical stage, candidiasis, CD4 count, tuberculosis, and hepatitis were all eligible for multivariate analysis. Correlation test among these factors also showed a weak correlation.

Multivariate analysis showed that HIV/AIDS patients at clinical stage IV were more likely to experience treatment failure than clinical HIV stage 
Table 1 Sociodemographic variables associated to treatment failure at Sanglah Hospital, Denpasar - Bali

\begin{tabular}{|c|c|c|c|c|c|c|}
\hline \multirow[b]{2}{*}{ Variables } & \multicolumn{3}{|c|}{ Bivariate } & \multirow[b]{2}{*}{ p value } & \multicolumn{2}{|c|}{ Multivariate } \\
\hline & $\begin{array}{c}\text { Control } \\
n(\%)\end{array}$ & $\begin{array}{l}\text { Cases } \\
\text { n (\%) }\end{array}$ & Crude OR & & Adjusted OR & $95 \% \mathrm{Cl}$ \\
\hline \multicolumn{7}{|l|}{ Age } \\
\hline$\leq 25$ year & $15(11.0)$ & $9(13.2)$ & Ref & & & \\
\hline 26-35 year & $85(62.5)$ & $45(66.2)$ & 0.88 & $0.356^{\mathrm{a}}$ & & \\
\hline$>35$ year & $36(26.5)$ & $14(20.6)$ & 0.65 & & & \\
\hline \multicolumn{7}{|l|}{ Marital status } \\
\hline Married & $84(61.8)$ & $39(57.4)$ & Ref & & Ref & \\
\hline Single & $46(33.8)$ & $19(27.9)$ & 0.89 & $0.048^{\mathrm{a}}$ & 0.86 & $0.42-1.69$ \\
\hline Widow/widower & $6(4.4)$ & $10(14.7)$ & 3.59 & & 3.69 & $1.21-11.27$ \\
\hline \multicolumn{7}{|l|}{ Education level } \\
\hline University & $11(8.1)$ & $10(14.7)$ & Ref & & & \\
\hline Junior-SeniorHigh & $110(80.9)$ & $46(67.7)$ & 0.46 & $0.112^{\mathrm{a}}$ & & \\
\hline Primary and under & $15(11.0)$ & $12(17.7)$ & 0.88 & & & \\
\hline \multicolumn{7}{|l|}{ Employement status } \\
\hline Employed & $104(76.5)$ & $49(72.1)$ & Ref & & & \\
\hline Unemployed & $32(23.5)$ & $19(27.9)$ & 1.26 & 0.493 & & \\
\hline
\end{tabular}

Notes: ${ }^{\mathrm{a}}=\mathrm{p}$ overall value

Table 2 Clinical risk factors associated to treatment failure at Sanglah Hospital, Denpasar - Bali

\begin{tabular}{|c|c|c|c|c|c|c|}
\hline \multirow[b]{2}{*}{ Variables } & \multicolumn{3}{|c|}{ Bivariate } & \multirow[b]{2}{*}{ p value } & \multicolumn{2}{|c|}{ Multivariate } \\
\hline & $\begin{array}{c}\text { Control } \\
\text { n (\%) }\end{array}$ & $\begin{array}{l}\text { Cases } \\
\text { n (\%) }\end{array}$ & Crude OR & & Adjusted OR & $95 \% \mathrm{Cl}$ \\
\hline \multicolumn{7}{|c|}{ Risk for HIV transmission } \\
\hline Sexual & $98(72.1)$ & $43(63.2)$ & Ref & & & \\
\hline PLWHA partner & $18(13.2)$ & $12(17.7)$ & 1.52 & $0.439^{\mathrm{a}}$ & & \\
\hline IDU & $20(14.7)$ & $13(19.1)$ & 1.48 & & & \\
\hline \multicolumn{7}{|c|}{ First line ART regiment } \\
\hline Standard & $95(69.8)$ & $49(72.1)$ & Ref & & & \\
\hline Non-standard & $41(30.2)$ & $19(27.9)$ & 0.90 & 0.745 & & \\
\hline \multicolumn{7}{|l|}{ Candidiasis (OI) } \\
\hline No & $59(43.4)$ & $21(30.9)$ & Ref & & & \\
\hline $\mathrm{OC}$ & $47(34.6)$ & $18(26.5)$ & 1.08 & $0.007^{\mathrm{a}}$ & & \\
\hline OEC & $30(22.0)$ & $29(69.1)$ & 2.72 & & & \\
\hline \multicolumn{7}{|l|}{ Tuberculosis (OI) } \\
\hline No & $89(65.4)$ & $53(77.9)$ & Ref & & Ref & \\
\hline Yes & $47(34.6)$ & $15(22.1)$ & 0.54 & 0.069 & 0.32 & $0.14-0.70$ \\
\hline \multicolumn{7}{|l|}{ Hepatitis (OI) } \\
\hline No & $126(92.7)$ & $58(85.3)$ & Ref & & & \\
\hline Yes & $10(7.4)$ & $10(14.7)$ & 2.17 & 0.102 & & \\
\hline \multicolumn{7}{|l|}{ Clinical HIV stage } \\
\hline Stage I-III & $94(69.1)$ & $34(50.0)$ & Ref & & Ref & \\
\hline Stage IV & $42(30.9)$ & $34(50.0)$ & 2.24 & 0.008 & 3.43 & $1.65-7.13$ \\
\hline \multicolumn{7}{|l|}{ CD4 count } \\
\hline$>200$ & $20(14.7)$ & $4(5.9)$ & Ref & & & \\
\hline$\leq 200$ & $116(85.3)$ & $64(94.1)$ & 2.75 & 0.075 & & \\
\hline
\end{tabular}


Table 2 Continue

\begin{tabular}{|c|c|c|c|c|c|c|}
\hline \multirow[b]{2}{*}{ Variables } & \multicolumn{3}{|c|}{ Bivariate } & \multirow[b]{2}{*}{ p value } & \multicolumn{2}{|c|}{ Multivariate } \\
\hline & $\begin{array}{c}\text { Control } \\
\text { n (\%) }\end{array}$ & $\begin{array}{l}\text { Cases } \\
\text { n (\%) }\end{array}$ & Crude OR & & Adjusted OR & $95 \% \mathrm{Cl}$ \\
\hline \multicolumn{7}{|l|}{ Hemoglobin level } \\
\hline Normal & $35(25.7)$ & $14(20.6)$ & Ref & & & \\
\hline Anemia & $101(74.3)$ & $54(79.4)$ & 1.34 & 0.418 & & \\
\hline \multicolumn{7}{|l|}{ BMI } \\
\hline Normal & $78(57.3)$ & $36(52.9)$ & Ref & & & \\
\hline Overweight & $7(5.2)$ & $5(7.4)$ & 1.54 & $0.641^{\mathrm{a}}$ & & \\
\hline Underweight & $51(37.5)$ & $27(39.7)$ & 1.14 & & & \\
\hline \multicolumn{7}{|l|}{ Drugs side effects } \\
\hline No substitution & $97(71.3)$ & $44(64.7)$ & Ref & & & \\
\hline Substitution 1 time & $27(19.9)$ & $20(29.4)$ & 1.63 & $0.279^{\mathrm{a}}$ & & \\
\hline Substitution $>1$ time & $12(8.8)$ & $4(5.9)$ & 0.73 & & & \\
\hline
\end{tabular}

Note: ${ }^{a}=$ p overall value

I-III $(A O R=3.45 ; 95 \% C I: 1.65-7.13)$. HIV/AIDS patients with treatment failure were more likely to be a widow/widower (AOR=3.69; 95\%CI: 1.21 11.27) as can be seen in Table 1. In contrast, HIV/ AIDS patients with tuberculosis co-infection prior to first line ART initiation were less likely to experience treatment failure than those without tuberculosis infection (AOR=0.32; 95\%CI: 0.14-0.70).

\section{DISCUSSION}

This study shows that the diagnosis of treatment failure among HIV/AIDS patients was delayed due to limited access. Late HIV/AIDS clinical stage and being widow/widower increase the risk of treatment failure. In contrast, co-infection with tuberculosis reduces the risk of treatment failure.

Diagnosis of treatment failure in this study is based on clinical criteria. Due to limited testing facilities at Sanglah Hospital, immunologic and virologic tests can only be offered to some patients who can afford it. Therefore the median time from ART initiation to the event of immunological failure (3.7 years) and virological failure (4.1 years) were longer than clinical failure (3.5 years). In contrast, existing studies showed that median time for diagnosing clinical failure is shorter than immunological and virological failures (1.4 to 2.5 years). ${ }^{36-40}$ Among all clinical failure cases in this study, $72.1 \%$ underwent immunologic confirmation test while only $36.8 \%$ underwent virologic confirmation test. All these patients were at late HIV/AIDS clinical stage (stage IV), with low CD4 count $\left(46\right.$ cells $/ \mathrm{mm}^{3}$ ) and high viral load (an average of 296.633 copies $/ \mathrm{ml}$ ). Similar situations have also been found in Malawi, Uganda and Zimbabwe that also use clinical diagnosis to determine treatment failure. ${ }^{39,40}$ Given the fact that Sanglah General Hospital is the referral centre for HIV/AIDS care in Bali Province, governments should support the provision of immunologic and virologic confirmation tests to prevent the delayed diagnosis.

This study also revealed that HIV/AIDS clinical stage IV increases the risk for treatment failure by 3.43 times than clinical stage I-III. Similar findings have also reported by numerous studies in Asia and Africa. ${ }^{12,15-18}$ As many as $39.3 \%$ of HIV/ AIDS patients at clinical stage IV in this study were diagnosed with severe OIs that include candidiasis esophageal (77.6\%), extra-pulmonary tuberculosis (48.7\%), severe anemia (39.3\%), hepatitis (19.7\%), and toxoplasmosis (9.2\%). In addition, they had low CD4 count $\left(23.5 \mathrm{sel} / \mathrm{mm}^{3}\right)$. Previous studies in India and Indonesia reported that patients at HIV/ AIDS clinical stage IV presented to hospital with severe OIs, low CD4 count and high viral load. ${ }^{30,31}$ Studies in Asia and Africa also showed that patients at late HIV/AIDS clinical stage often presented to health facilities with severe OIs and low CD4 count. Due to these clinical conditions, they required a longer recovery period and a high adherence rate. Therefore they tended to have higher risk of developing treatment failure. ${ }^{13-16,32}$

HIV/AIDS patients co-infected with tuberculosis seem to have a lower risk of treatment failure. The implementation of TB-HIV collaboration leads to an early HIV diagnosis among tuberculosis patients followed by an early ART initiation. HIV-TB co-infection patients receive monitoring from Directly Observed Treatment Short Course (DOTS) program as well as from VCT program - leading to better adherence towards HIV and TB treatments. From all TB-HIV co-infection cases in this study, 40.3\% HIV status were confirmed after the TB 
diagnosis. The majority of these patients (82.3\%) received ART at four weeks after the commencement of TB treatment. DOTS program facilitates treatment compliance for both HIV and TB. Studies in Kenya and South Africa have also revealed that TB-HIV collaboration improves compliance towards ART and reduces drop out of TB medication. ${ }^{33,34}$ However, previous studies in West Java and South Africa found that HIV-TB co-infection was not associated with treatment failure. ${ }^{12,20}$

Being widow/widower increases the risk of treatment failure when compared to married HIV/ AIDS patients. This finding is consistent with study conducted in Brazil ${ }^{35}$ however the proportion of widow/widower in the present study was small (only 7.8\% from total sample). Therefore, this finding should be interpreted with caution.

This study has several limitations. Primary source of data in this study is medical record that is often incomplete and confirmation from other sources is required. This may influence the internal validity of this study. Several key factors associated to treatment failure are unavailable for example data on compliance rate to ART. In this study, drugs could also be taken not directly by patients thus making it difficult to accurately measure patients' compliance. HIV patients only present to the clinic if they experience symptoms associated to treatment failure. Since controls were selected using convenience method, it may not accurately represent the control population.

\section{CONCLUSION}

Clinical diagnosis of treatment failure is delayed. This delay leads to deterioration of patients' clinical conditions. In addition, severe clinical conditions can increase the risk of first line ART failure. TB-HIV co-infection reduces the risk of treatment failure due to early diagnosis and treatment. Monitoring of viral load is essential to prevent ART failure or CD4 count monitoring if viral load test is not available.

\section{ACKNOWLEDGEMENT}

We would like to thank the hospital director and all staff of Nusa Indah VCT Clinic Sanglah General Hospital for supporting this study.

\section{REFERENCES}

1. Ministry of Health of Indonesia. Pedoman Nasional Tatalaksana Klinis Infeksi HIV dan Terapi Antiretroviral pada Orang Dewasa [National Guideline on Clinical Management of HIV Infection and ART for Adult]. Jakarta: Kementerian Kesehatan RI; 2011.
2. WHO-HIV Treatment. Global Update on HIV Treatment 2013; Result, Impact and Opportunities. Geneva Switzerland: Publications of the World Health Organization; 2013.

3. WHO-Technical Report. Antiretroviral Medicines in Low and Middle Income Countries: Forecasts of Global and Regional Demand for 2014-2018. Geneva Switzerland: Publications of the World Health Organization; 2015.

4. Duong AT, Kato M, Bales. Costing Analysis of National HIV Treatment and Care Program in Vietnam. J Acquir Immune Defic Syndr; 2014; 65: 1-7.

5. Long L, Fox M, Sannea I, Rosena S. The high cost of second-line antiretroviral therapy for HIV/AIDS in South Africa; 2010; 24: 915-919.

6. Castelnuovo B, John LD, Lutwama F, Ronald A, Spacek LA, Bates M, Kamya MR, Colebunders R. Three-Year Outcome Data of Second-Line Antiretroviral Therapy in Ugandan Adults: Good Virological Response but High Rate of Toxicity. Journal of the International Association of Physicians in AIDS Care; 2009; 8: 52-59.

7. Yuniar Y, Syaripuddin M, Isakh BM, 2014. Manajemen Logistik Obat Antiretroviral di Indonesia [Logistic Management of Antiretroviral in Indonesia]. Buletin Penelitian Sistem Kesehatan; 2011; 17: 125-134.

8. WHO-HIV/AIDS Media Center. Key Facts HIV/AIDS. Geneva Switzerland: Publications of the World Health Organization; 2015.

9. Madec Y, Leroy S, Cuille MAR, Huber F, Calmy A. Persistent Difficulties in Switching to Second-Line ART in Sub-Saharan Africa - A Systematic Review and MetaAnalysis. PLoS One; 2014; 9(4): e95820.

10. Trotter AB, Hong SY, Srikantiah P, Abeyewickreme I, Bertagnolio S, Jordan MR. Systematic Review of HIV Drug Resistance in the World Health Organization Southeast Asia Region. AIDS Rev; 2013; 15 (3): 162-170.

11. Subuh M. Laporan Perkembangan HIV-AIDS Triwulan I Tahun 2015 [HIV/AIDS Update Report First Trimester 2015]. Surat Edaran pada Pertemuan Monitoring dan Evaluasi Nasional HIV-AIDS Tengah Semester 2015. Jakarta 8-12 Juni; 2015.

12. Fox MP, Van Cutsem G, Giddy J, Maskew M, Keiser O, Prozesky H, Wood R, Hernan MA, Sterne JAC, Egger M, Boulle A. 2009. Rates and Predictors of Failure of First-line Antiretroviral Therapy and Switch to Second-line ART in South Africa. J Acquir Immune DeficSyndr; 2012;60(4): 428-437.

13. Chandya S, Singha G, Heylenb E, Gandhic M, Ekstrand ML. Treatment switching in South Indian patients on HAART: What are the predictors and consequences. AIDS Care; 2011; 23(5): 569-577.

14. Palombi L, Marazzi MC, Guidotti G, Germano P, Buonomo E, Scarcella P, Altan AD, Zimba IDVM, Lio MMS, Luca AD. Incidence and Predictors of Death, Retention, and Switch to Second-Line Regimens in Antiretroviral-Treated Patients in Sub-Saharan African Sites with Comprehensive Monitoring Availability. Clinical Infectious Diseases-Oxford University; 2009; 48(1): 115-122

15. Abah IO, Darin KM, Ebonyi AO, Ugoagwu P, Ojeh VB, Nasir N, Falang KD, Olaitan O, Agbaji O, Idoko J, Kanki P. Patterns and Predictors of First-Line Antiretroviral Therapy Modification in HIV-1-Infected Adults in a Large Urban Outpatient Cohort in Nigeria, Journal of the International Association of Providers of AIDS Care; 2015; 14(4) : 348-354.

16. Hawkins C, Achenbach C, Fryda W, Ngare D, Murphy R. Antiretroviral Durability and Tolerability in HIVInfected Adults Living in Urban Kenya. J Acquir Immune DeficSyndr; 2007; 45: 304-310.

17. Penot P, Hema A, Bado G, Kabore F, Sore I, Sombie D, Traore JR, Schmid JBG, Fontanet A, Slama L, Sawadogo AB, Laurent $C$. The vulnerability of men to virologic failure during antiretroviral therapy in a public routine clinic in Burkina Faso. Journal of the International AIDS Society; 2014, 17:18646. 
18. Jiamsakul A, Sungkanuparph S, Law M, Kantor R, Praparattanapan J, Li PCK., Phanuphak P, Merati T, Ratanasuwan W, Lee CKC, Ditangco R, Mustafa M, Singtoroj T, Kiertiburanakul S. HIV Multidrug Resistance at First Line Antiretroviral Failure and Subsequent VirologicalRespone in Asia. Journal of the International AIDS Society; 2014, 17:19053-19063.

19. Robbins GK, Daniels B, Zheng H, Chueh H, Meigs JB, Freedberg KA. Predictors of Antiretroviral Treatment Failure in an Urban HIV Clinic. J Acquir Immune Defic Syndr; 2007; 44 (1): 30-37.

20. Fibriani A, Wisaksana R, Indrati A, Hartantri Y, Vijver D, Schutten M, Alisjahbana B, Sudjana P, Boucher CAB., Crevel R, Ven A. Virological Failure and Drug Resistance during First Line Anti-Retroviral Treatment in Indonesia. J. Med. Virol; 2013; 85:1394-1401.

21. Beaudrap PD, Thiam M, Diouf A, Toure-Kane C, NgomGuèye NF, Vidal N, Mboup S, Ndoye I, Sow PS, Delaporte E. Risk of Virological Failure and Drug Resistance during First and Second-Line Antiretroviral Therapy in a 10-Year Cohort in Senegal: Results From the ANRS 1215 Cohort. J Acquir Immune DeficSynd; 2013; 62: 381-387.

22. Vanobberghen FM, Kilama B, Wringe A, Ramadhani A, Zaba B, Mmbando D, Todd J. Immunological failure of first-line and switch to second-line antiretroviral therapy among HIV-infected persons in Tanzania: analysis of routinely collected national data. Tropical Medicine and International Health; 2015; 20 (7): 880-892.

23. Charles M, Leger PD, Severe P, Guiteau C, Apollon A, Gulick RM, Johnson WD, Pape JW, Fitzgerald DW. Virologic, clinical and immunologic responses following failure of first-line antiretroviral therapy in Haiti. Journal of the International AIDS Society; 2011; 15:17375

24. Gras G, Schneider MP, Cavassini M, Lucht F, Loilier M, Verdon R, Bernard L, Parienti JJ. Patterns of Adherence to Raltegravir-Based Regimens and the Risk of Virological Failure among HIV-Infected Patients: The RALTECAPS Cohort Study. J Acquir Immune DeficSyndr; 2012; 61 (3): 265-269.

25. Jespersen S, Hønge BL, Medina C, Te DS, Correira FG, Laursen AL, Erikstrup C, Østergaard L, Wejse C. Lack of awareness of treatment failure among HIV-1-infected patients in Guinea-Bissau-a retrospective cohort study. Journal of the International AIDS Society; 2015; 18:20243.

26. Leng X, Liang S, Ma Y, Dong Y, Kan W, Goan D, Hsi JH, Liao L, Wang J, He C, Zhang H, Xing H, Ruan Y, Shao Y. HIV virological failure and drug resistance among injecting drug users receiving first-line ART in China. $B M J$ Open; 2014; 4: e005886.

27. Caseiro MM, Golegã AAC, Etzel A, Diaz RS. Characterization of Virologic Failure After an Initially Successful 48-Week Course of Antiretroviral Therapy in HIV/AIDS Outpatients Treated in Santos, Brazil. The Brazilian Journal of Infectious Disease; 2008; 12(3):162-166.

28. Lynen L, An S, Koole O, Thai S, Ros S, Munter P, Sculier D, Arnould L, Fransen K, Menten J, Boelaert M, Ende J, Colebunders R. 2008. An Algorithm to Optimize Viral Load Testing in HIV-Positive Patients with Suspected First-Line Antiretroviral Therapy Failure in Cambodia. $J$ Acquir Immune DeficSyndr 2009; 52: 40-48.

29. Bali Provincial Health Office. Profil Dinas Kesehatan Provinsi Bali. [Profile of Bali Provincial Health Office]. Denpasar. Dinas Kesehatan Provinsi Bali; 2015.
30. Utama MS, Merati TP. Association of Opportunistic Infections with HIV RNA and CD4 Cell Count in Pre ARV and ARV Failure at The Care Support Treatment Clinic of Sanglah Hospital Bali. Journal of Epidemiological Research; 2016; 2 (2): 13-17.

31. Ghate M, Deshpande S, Tripathy S, Nene M, Gedam P, Godbole S, Thakar M, Risbud A, Bollinger R, Mehendale S. Incidence of common opportunistic infections in HIVinfected individuals in Pune, India: analysis by stages of immunosuppression represented by CD4 counts. International Journal of Infectious Diseases; 2009; 13: 1-8

32. Parto DN, Budhi A, Arifin N. 2008. Factors Associated to Success Tuberculosis Therapy of Co-infection TB-HIV Patients in Persahabatan Hospital, Jakarta-Indonesia. J Respir Indo; 2011; 31 (1).

33. Neel GR, Moll AP, Lalloo U, Pawinski R, Zeller K, Moodley P, Meyer E, Friedland G. Successful Integration of Tuberculosis and HIV Treatment in Rural South Africa. J Acquir Immune DeficSyndr; 2009;50:37-43

34. Owiti P, Zachariah R, Bissel K, Kumar AMV, Diero L, Carter EJ, Gardner A. 2012. Integrating Tuberculosis and HIV Services in Rural Kenya, Uptake and Outcomes. Public Health Action; 2015; 5(1): 36-44

35. Caseiro MM, Golegã AAC, Etzel A, Diaz RS. Characterization of Virologic Failure After an Initially Successful 48-Week Course of Antiretroviral Therapy in HIV/AIDS Outpatients Treated in Santos, Brazil. The Brazilian Journal of Infectious Diseases; 2008; 12 (3):162-166.

36. Sungkanuparph S, Groger RK, Overton ET, Fraser VJ, Powderly WG. 2006. Persistent Low Level Viraemia and Virological Failure in HIV-1 Infected Patients Treated with Highly Active Antiretroviral Therapy. HIV Medicine; 2006; 7: 437-441.

37. Ma Y, Zhao D, Yu L, Bulterys M, Robinson ML, Zhao Y, Dou Z, Chiliade Z, Wei X, Zhang F. Predictors of virologic failure in HIV-1-infected adults on first line antiretroviral therapy in eight provinces in China. Clinical Infectious Diseases; 2009; $50: 264-271$

38. Romanee C, Charussri W, Wilai K, Jutharat P, Thira S, Khuanchai S. Sensitivity and Specificity of Using CD4 Measurement and Clinical Evaluation to Determine Antiretroviral Treatment Failure in Thailand. International Journal of Infectious Diseases; 2007; 11: 413-416.

39. Gsponera $T$, Petersenb $M$, Eggera $M$, Phirid S, Maathuise MH, Boullec A, Musondadf P, Tweyad H, Petere K, Chig BH, Keisera O. The Causal Effect of Switching to Second-line ART in Programmes without Access to Routine Viral Load Monitoring. AIDS; 201; 26(1): 57-65.

40. Gilks CF, Walker AS, Munderi P, Kityo C, Reid A, Katabira E, et al. A Single CD4 Test with 250 cells $/ \mathrm{mm}^{3}$ Threshold Predicts Viral Suppression in HIV-Infected Adults Failing First-Line Therapy by Clinical Criteria. Published: Feb 21, 2013 http://dx.doi.org/10.1371/journal. pone. 0057580

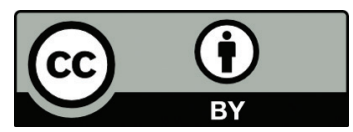

This work is licensed under a Creative Commons Attribution 